УДК 342.8:32

https://doi.org/10.52058/2786-5274 -2022-2(4)-99-110

Правдюк Андрій Леонідович кандидат юридичних наук, доцент кафедри права, Вінницький національний аграрний університет, вул. Сонячна 3, м. Вінниця, 21000, тел.: (097) 330-72-40, https://orcid.org/ 0000-0002-5248-8111

Петрище Леся Ярославівна студентка II курсу, факультету менеджменту та права, Вінницький національний аграрний університет, вул. Сонячна 3 , м. Вінниця, 21000, тел.: (096) 560-41-05

\title{
ВИБОРЧА ІНЖЕНЕРІЯ В КОНТЕКТІ ПОЛІТИЧНИХ ТРАНСФОРМАЦЙ
}

Анотація. Стаття присвячена дослідженню проблем становлення та розвитку виборчої інженерії в Україні. Висвітлені гносеологічні витоки виборчої інженерії як наукового напряму та теоретико-методологічні засади конституційно-правового конструюваннявиборчої системи та процесу. Проаналізовано гносеологічні, політичні, правові засади конституційної інженеріїю. Розкривається суть виборчої інженерії як складову системи політичного маркетингу, а також іiі вплив на політичний ринок. Розглянуто основні методи виборчої інженерії, що сьогодні використовуються в політичному менеджменті. Визначено, що взаємодія людини і політики пов'язана із вибором, завдяки якому вона визначає свою позицію, напрями політичної діяльності, обирає партнерів чи приєднується до тієї чи іншої політичної сили. Зазначено політичне поле України в цілому має ринковий вимір. Він як систему включає ринок іміджів політичних лідерів і партій, у його межах «просувається товар», орієнтований на різні смаки «покупців». Потрібно підкреслити, що соціальна роль та значення сучасного вітчизняного політичного ринку полягає в тому, щоб забезпечити демократичне функціонування політичної сфери, вивчення попиту й підготовку пропозиції «політичного товару», цивілізоване змагання різних політиків, партій та програм. Визначено, що виборча інженерія - це цілеспрямований процес формування та вдосконалення системи народного представництва (системи організації виборів та пов'язаних із нею відносин) у громадських органах влади та місцевого самоврядування. Зясовано, що становлення національної державності та процеси трансформації політичної системи в Україні актуалізують вивчення інституту виборів як одного $з$ фундаментальних основ демократії та необхідного елемента сучасного суспільного інституту. Будучи найважливішим компонентом сучасної політики, інститут виборів забезпечує формування органів влади та управління за допомогою виразу та організації за 
певними правилами та процедурами політичної волі громадян.

Ключові слова: вибори, виборча інженерія, політичний вибір, політичні цінності, свобода, відповідальність, чинники політичного вибору.

Pravdiuk Andrii Leonidovych Candidate of Law Sciences, Associate Professor of the Department of Law, Vinnytsia National Agrarian University, Sonyachna St., 3, Vinnytsia, 21000, tel.: (097)330-72-40, https://orcid.org/0000-0002-5248-8111

Petryshche Lesya Yaroslavivna Student, Faculty of Management and Law, Vinnytsia National Agrarian University, Sonyachna St., 3, Vinnytsia, 21000, tel.: (096) 560-41-05

\title{
ELECTORAL ENGINEERING IN THE CONTEXT OF POLITICAL TRANSFORMATIONS
}

\begin{abstract}
The article is devoted to the study of the problems of formation and the development of electoral engineering in Ukraine. The epistemological origins of electoral engineering as a scientific direction and theoretical and methodological principles of constitutional and legal construction of the electoral system and process are highlighted. The epistemological, political, legal bases of constitutional engineering are analyzed. The essence of electoral engineering as a component of the political marketing system, as well as its impact on the political market is revealed. The main methods of electoral engineering used today in political management are considered. It is determined that the interaction of man and politics is associated with the choice by which he determines his position, direction of political activity, chooses partners or joins a particular political force. This political field of Ukraine as a whole has a market dimension. As a system, it includes the market of images of political leaders and parties, within which "goods are promoted", focused on different tastes of "buyers". It should be emphasized that the social role and importance of the modern domestic political market is to ensure the democratic functioning of the political sphere, the study of demand and supply of "political goods", civilized competition of various politicians, parties and programs. It is determined that electoral engineering is a purposeful process of formation and improvement of the system of people's representation (system of organization of elections and related relations) in public authorities and local self-government. It is found that the formation of national statehood and the processes of transformation of the political system in Ukraine actualize the study of the institution of elections as one of the fundamental foundations of democracy and a necessary element of a modern social institution. As the most important component of modern politics, the institution of elections ensures the formation of government and administration through expression and organization according to certain rules and procedures of political will of citizens.
\end{abstract}


Keywords: elections, electoral engineering, political choice, political values, freedom, responsibility, factors of political choice.

Постановка проблеми. У демократичній державі вибори мають гарантувати верховенство народної волі, іiі втілення у діяльності органів державної влади, високий рівень відповідальності держави перед громадянським суспільством. Забезпечення вільних, рівних, справедливих справді демократичних політичних виборів - одне з найважливіших завдань i держави та суспільства. Процес удосконалення політико-правових засад функціонування виборчої системи можна розглядати як найважливішу умову підвищення ефективності організації та проведення виборів, забезпечення та захисту політичних прав громадян.

Вибори у законодавчі та представницькі органи влади відіграють надзвичайно важливу роль у політиці. Вони $є$ не лише головним інститутом, а й $\epsilon$ лакмусовим папірцем розвитку демократії i ставлення держави до прав людини загалом. Від того як організовано електоральний процес, ступеня його демократичності, активності виборців тощо, залежить якість провідної верстви країни, яку ми обираємо й, відповідно, доля країни. Апріорі передбачається, що при демократії влада має діяти в інтересах більшості, але насправді це не завжди так. Зрозуміло, що інтереси політичних суб'єктів не завжди співпадаютьзі справжніми національними або суспільними потребами.і це $\epsilon$ природнім, оскільки політична сила, що приходить до влади, найбільш стурбована збереженням свого положення, тому скоріше діє у власних інтересах, які зовсім не обов'язково співпадають із суспільними.

Аналіз останніх досліджень і публікацій із цієї теми свідчить, що дослідженню виборчої інженерії та виборчим правам громадян були присвячені праці багатьох вчених, зокрема: Н.Н. Бабочива, Ф.А. Хайек, Ю. Шведа, А.Л. Правдюк, Н.М. Опольська, В.М. Бебик, С.І. Здіорук, М. Кот , С. В. Лазаренко, М.В. Афанасьєва та інших.

Метою статті є дослідження проблем становлення та розвитку виборчої інженерії в Україні.

Виклад основного матеріалу. Ознакою демократичності, здатності до розв'язання нагальних суспільно-політичних проблем мирними політичними методами вважається готовність суспільства до проведення виборів, які $\epsilon$ легалізованим політичним конфліктом у боротьбі за політичну владу. Сучасні державотворчі процеси яскраво характеризують Україну як незалежну державу перехідної демократії. Зокрема, це підтверджує постійний розвиток системи законодавства України та зменшення кількості нормативних актів, що дістались нам у спадок ще з радянських часів. Однак, якщо вести мову безпосередньо про виборче законодавство, то не можна обійти увагою той факт, що воно 3 проголошенням незалежності України $\epsilon$ дуже нестабільним. однак, проблема не стільки в динаміці окреслених змін (адже така властивість 
характерна поставторитарним молодим демократіям), а у поверхневому, вузькополітизованому, поспішному процесі виборчої інженерії [1, с 134]. У цьому контексті М. О. Баймуратов та I. Д Сліденко зазначають: «Динаміка процесу трансформації парламентської виборчої системи України з усією очевидністю показує основну іï особливість - відсутність наукового підходу до інсталяції виборчої системи в парламент, в існуючу в Україні правову модель» [2, с. 30].

Ключовим інструментом формування представницької влади завжди були вибори Вибори це комплексне явищем, яке грунтується не тільки на законодавстві, а й на історичних традиціях, культурі, політиці, моралі та демократичних цінностях суспільства. Тому закономірним $\epsilon$ напрацювання механізмів отримання максимально вигідного очікуваного результату виборів. Одним $з$ таких інструментів $\epsilon$ саме виборча інженерія як легальне (проте не завжди легітимне) встановлення (або зміна) вихідних правил виборчого процесу.

Запозичений 3-за кордону та поширений сьогодні термін «виборча інженерія» використовується як у публіцистичній, так і в науковій літературі, але при цьому жодна суспільна наука не виробила однакового розуміння та чіткого визначення цього феномена.

За тлумачним словником російської мови за редакцією С. Ожегова та Н. Шведової, етимологічно слово «інженерія» далеке від соціальних та політико-правових процесів і безпосередньо відноситься до технічних наук та природознавства. Воно визначається як:

1) творча технічна діяльність;

2) конструювання нових, не існуючих в природі органічних одиниць [3, с. 247].

У науковий обіг термін «соціальна інженерія» вперше увів Р. Паунд у 1922 році працею «Вступ до філософії права» (за іншими відомостями, зазначений термін з'явився раніше, його застосування приписують С. і Б. Веббам). К. Поппер визначав соціальну інженерію як діяльність 3 проектування нових соціальних інститутів, а також перебудову та управління вже існуючими соціальними інститутами шляхом поступових реформ та змін. Необхідними вихідними умовами соціальної інженерії він вважав формулювання, хоча б у вигляді начерку, кінцевої мети та одержання чогось подібного до проекту суспільства, до якого прагнемо. Тільки після цього можемо починати аналіз найкращих способів i засобів утілення цього проекту й намітити план практичних дій [4, с. 262].

У середині XX століття окремі вчені пропонували відмовитися від поняття «соціальна інженерія» у зв'язку з тим, що воно стало предметом ідеологічних спекуляцій. Так, Ф. А. фон Хайек заперечував використання цього поняття, вбачаючи в ньому намагання провести ідею централізованого планування суспільних процесів з боку держави. Він вважав соціальну інженерію спробою побудувати суспільство відповідно до певної визначеної раціональної моделі (схеми), в якій нема місця індивідуальній свободі [5]. 
Політологи, що спеціалізуються на підготовці та проведенні виборчих кампаній, розглядають «виборчу інженерію» як область прикладної політології, що вивчається політичним маркетингом. При цьому поряд 3 терміном «виборча інженерія» використовуються також поняття «політична» та «електоральна інженерія», «інституціональний» та «електоральний дизайн», деякі автори їх ототожнюють, інші розширюють зміст одного за рахунок характеристик іншого [6, с 12]. В свою чергу хотілось би зазначити що так звані політологи в Україні це зазвичай колишні й нинішні політики, що не мають фахової освіти, але інформовані про політичне життя завдяки особистим зв'язкам з політиками діючими., i тому як не згадати знамениту фразу У. Черчілля про те, що «Політик повинен уміти пророчити, що може відбутися завтра, на наступному тижні, через місяць, через рік. А потім пояснити, чому цього не відбулося» [7].

Ю. Шведа вважає, що виборча інженерія - це наука про впровадження нових елементів у виборчу систему [8], при цьому останню він розглядає як спосіб розподілу представницьких мандатів залежно від результатів голосування, тобто в його розумінні мова йде про вибір оптимального варіанта підрахунку голосів, який дозволив би збалансувати плюси та мінуси різних видів виборчої системи з урахуванням політичних реалій у державі.

Конституційно-правову науку i практику, передовсім, цікавить конституційно-правове забезпечення виборчої інженерії. Громадськістю виборча інженерія здебільшого сприймається як маніпуляції 3 виборчим законодавством і підстави для цього у нашій державі є. Сучасний етап розвитку українського суспільства характеризується низькими показниками довіри громадян України до владних інституцій. Передусім це обумовлено недоліками правового змісту, відсутністю чітких інструкцій i процедур, низькою правовою культурою суб'єктів виборчого процесу [9, с,12]. Варто зазначити, що чимало виборчих маніпуляцій не дозволяють в повному обзязі реалізувати права людини та громадянина на вільне волевиявлення, адже права людини в сучасному світі - це не просто актуальна тема для дискусій, це проблема, вирішення якої стоїть у центрі практичної діяльності міжнародного співтовариства. Захист прав людини і громадянина є конституційно-правовим $i$ міжнародно-правовим обов'язком сучасних держав, який реалізується за допомогою системи принципів, інститутів, механізмів і процедурно-правових правил, що прямо або опосередковано передбачені для цих цілей [10, с. 9].

В. Бебик розглядає виборчу інженерію як пристосування виборчих процедур до реалізації інтересів правлячих політичних еліт щодо завоювання та збереження влади в державі, регіоні, місті, районі і т. д. [11, с. 68]. Як зазначають С. Здіорук та В. Бичек, характер партійно-політичного процесу в Україні значною мірою визначає взаємодія адміністративно-економічних угруповань і політичних партій в Україні, які тяжіють до зближення, оскільки великий капітал за допомогою політичних партій може легалізувати своє прагнення прийти в політику, партії ж, зі свого боку, забезпечують таким чином 
фінансування своєї діяльності. Небезпека такої співпраці полягає у перетворенні партій у формат своєрідних бізнес-проектів, що створюються як об'єднання із залученням бюрократичного апарату для лобіювання власних інтересів певної адміністративно-економічної групи, а не для розробки та впровадження стратегічних концепцій розвитку українського суспільства [12, с. 91].

Від часу зламу монополії Комуністичної партії, отримання незалежності та розвитку багатопартійності соціологи фіксують переважно негативне суспільне ставлення в Україні до політичних партій. Індикаторами цього, як свідчить ціла низка досліджень, слугують низький рівень довіри, невисокий показник членства в партіях, неготовність до матеріальної підтримки політичних сил. 3 іншого боку, і самі партії, яких в Україні, згідно з офіційними даними міністерства юстиції, зареєстровано понад 350 (хоч i не всі з них активні), упродовж багатьох років взаємодіяли 3 електоратом 3 позицій патерналізму, приміром, за горезвісною формулою "гречка в обмін на голос". При цьому, ідеологічна складова часто-густо відігравала другорядну роль, а "партіїодноденки", створені під вибори, сходили з політичного ландшафту, виконавши свою скромну роль[13]. При цьому діяльність партій це як формування класичного бізнес - плану, залучення інвесторів; планування господарської діяльності фірми на найближчий і віддалений періоди відповідно до потреб ринку та можливостей отримання необхідних ресурсів; оформлення документів на отримання інвестицій, отримання бажаного результату діяльності протягом певного часу. На спорідненість демократії та ринку вказував ще Платон, стверджуючи, що обидва ці явища надають громадянам одну й ту ж можливість - можливість вибирати [14, с. 345]. Незважаючи на всі його вади, політичний ринок створює таке конкурентне середовище, в якому народжуються альтернативні концепції державотворення та управління, урядові курси і програми, дієві політичні партії, рухи тощо. Крім того, політичний „товар” - політичні лідери, партії, рухи, програми - подібні до товарів на економічному ринку. Будь-який продукт має свою форму, колір, спосіб використання. Те ж саме стосується й політика, який має свою програму, імідж, команду, форми діяльності. Споживчі властивості товару зазначені на його етикетці. Натомість політична партія, довірені особи, репутація, попередня діяльність характеризують політичного лідера [15, с. 280].

На наш погляд цілком зрозумілим $\epsilon$ те що виборча інженерія $\epsilon$ невід'ємною складовою виборчого закону та виборчих процедур, адже провладні суб'єкти завжди будуть застосовувати маніпулятивні технології. Ми вважаємо, що основними проблемами формування культури політичного вибору в українському суспільстві як патерналізм, деформація правової свідомості, «розмитість» системи політичних і правових цінностей, правовий нігілізм, деформація морально-етичної сфери тощо. Крім цього на жаль потрібно врахувати українські реалії, а саме фактори політичної корупції, незаконної агітації, застосування адміністративного ресурсу, порушення 
порядку підрахунку голосів, абсентеїзму тощо.

3 великою вірогідністю можем зазначити що виборець першочергово формує свою систему цінностей, а потім робить свій вибір. Очевидним є те, що громадянин немаючи розвиненої шкали політичних цінностей не зможе здійснити якісний політичний вибір. Так, С. Барбаранеллі, К. Капанна, Г. Капрара та ін. констатують, що цінності й голосування можуть мати взаємні впливи, які актуалізуються 3 двох причин. По-перше, політичні цінності стосуються того, що до6ре а6о погано для суспільства й країни. Тому під час здійснення політичного ви6ору реалізація базових цінностей хвилює всіх, оскільки це впливає на всі сфери індивідуального життя. Подруге, виборчі контексти у різних країнах розрізняються, що потребує додаткових уточнень ролі цінностей в них. Однак, вищеозначені автори підкреслюють, що під час передвиборчих кампаній, політична мо6ілізація може викликати зміни в ядрі політичних цінностей [16, с. 24].

В свою чергу М. Кот, який уявляє виборчу інженерію як намагання політичних партій, що мають владу приймати рішення в законодавчих органах, використовувати можливості, пов’язані зі зміною правил, на підставі яких проводяться вибори, вважає беззаперечним висновок про те, що таке ставлення суперечить ідеям, які лежать в основі демократії [17, с. 115].

Суб'єкти виборчої гонки, враховуючи наявні у їхньому розпорядженні ресурси, активно розробляють та впроваджують виборчі технології, займаються практичною соціально-інженерною діяльністю. В очах громадськості виборчі технології здебільшого сприймаються виключно як маніпуляції, але технологічність виборчої сфери спрямована насамперед на іï стандартизацію, раціоналізацію, ефективність і не означає апріорі протиправну.

Інженерно-технологічний підхід до виборчого права і процесу широко обговорюється в журналістиці та політичній практиці, але в юридичній літературі він не отримав всебічного наукового аналізу. Тому актуальним $\epsilon$ вивчення сутності виборчої інженерії та виборчих технологій, їх конституційно-правового забезпечення, розробка шляхів мінімізації використання незаконних i неправомірних проявів інженерно-технологічної діяльності в рамках виборчих кампаній. Таким чином, на думку А. Р. Крусян, «модернізація Конституції України перед усім, повинна бути спрямована на усунення існуючих дефектів і прогалин у конституційному законодавстві» [18]. Ця проблема є важливою і актуальною не тільки для України, але й для будьякої іншої держави, тому що в конституції будь-якої держави (не тільки України) можливі дефекти та прогалини, подолання яких є необхідною умовою розвитку сучасного українського конституціоналізму. На думку М. В. Афанасьєвої, важливу роль в конституційній інженерії відіграють виборчі технології [6]. На думку автора, на сучасному етапі виборчі кампанії це чітко спланований процес з визначеними способами та етапами здійснення. Суб'єкти виборчих перегонів з урахуванням ресурсів, які є в їх розпорядженні, активно 
проектують та впроваджують у практику виборчі технології, займаючись практично соціально-інженерною діяльністю [6, с 17].

С. Устименко не використовує термін «виборча інженерія», але, на його думку, виборчі технології можна поділити на зовнішні (або нормативні), виходячи зі створення та функціонування організаційно-правової інфраструктури виборів (виборчого законодавства, системи виборчих комісій, конфігурації виборчих округів тощо); та внутрішні (або конкурентні) технології в рамках окремої виборчої кампанії, які дозволяють кандидату на виборну посаду та його команді домогтися оптимального впливу на виборців для досягнення поставлених цілей [19, с. 25].

Конституційна інженерія в Україні на сучасному етапі також розвивається 3 урахуванням норм, закріплених у ст. 11 Закону України «Про засади внутрішньої та зовнішньої політики». Серед норм зовнішньої політики України, визначених цими нормами, є орієнтація на «забезпечення інтеграції України до європейського політико-правового простору» 3 досить чіткою орієнтацією на міжнародні стандарти та європейський вимір конституційної інженерії на сучасному етапі. Конституційна глобалізація відображає не тільки кількісні, а й якісні характеристики правового життя. Його фокусом $є$ зростання універсальних у нормативно-правових стандартах сучасної цивілізації, тоді як у системі універсальних правових стандартів провідна роль належить демократичним інститутам сучасного конституціоналізму, центральними серед яких є права людини та міжнародні механізми їх захисту [20].

У сучасному світі модернізація є невід'ємною частиною універсальної тенденції глобалізації, в якій відбувається переплетення, дифузія внутрішніх i міжнародних криз, конфліктів i протиріч, а трансформація суспільства i держави визначається системою універсальних принципів людського розвитку. у процесі політичної модернізації є подолання деструктивної поведінки еліти, здійснення адміністративної реформи. У сучасній Україні партійний елітарний патерналізм динамічно ,збагатився” нормами олігархічного правління, що дозволило відкрито використовувати владу в інтересах окремих кланів, груп впливу. Здійснюється напівкримінальне і кримінальне зрощення політичної, економічної, фінансової і правоохоронної еліт, що обслуговують інтереси одна одної, створюючи могутні об’єднання. Масштабне розкрадання державного i колективного майна, хабарництво, протекціонізм стали нормою функціонування владних структур. Тому політична еліта дискредитуючи себе, дискредитує цілі і завдання демократичного розвитку й об'єктивно стає гальмом такого розвитку. Подальше збереження розриву між елітою і масами $\epsilon$ не тільки неприпустимим, а й соціально небезпечним й, відповідно, потребує здійснення адміністративної реформи [21].

Іншим важливим фактором конституційної інженерії $\epsilon$ побудова самого Основного Закону. Ефективна дія конституції та гарантія якісного виконання іiі політичних, організаційних, ідеологічних, соціальних, правових та інших 
функцій в інтересах народу $\epsilon$ змістом тексту, який безпосередньо взаємопов'язаний 3 конституційним процесом як механізмом. для його розробки та прийняття. Конституційно-правове конструювання виборчої системи є одним 3 найважливіших та найбільш складних конституційноправових видів діяльності, необхідних для утвердження демократії в державі. Залежно від конституційно-правової конструкції виборчої системи інститут виборів може або сприяти конструктивному розвитку політичної системи, коли забезпечується відкритість, конкуренція та відповідальність політичних сил, або деструктивно впливати на політичну сферу, коли на користь держави обмежується політичний плюралізм, встановлюється клановість політики й атомізація політичних сил [22, с. 134]. В свою чергу незважаючи на те, що виборча система є фундаментом формування публічної влади, але традиційно його положення не регламентується конституціями країн, а передбачаються поточним законодавством. I тому вибоча система $\epsilon$ більш гнучкою до впровадження новацій та здатна кон'юнктурно реформуватись та модернізуватись.

Висновки. Враховуючи витоки виборчої інженерії, можна розуміти різні категорії, найважливішими є «конституційна модернізація» та «конституційна реформа». Якщо концепція конституційної реформи пов'язана 3 прийняттям нового тексту Конституції, то конституційна модернізація покликана вдосконалити процес суспільно-політичних, економічних перетворень, оновлення всіх партій і сфер життя суспільства і держави. Конституційна інженерія має на меті розвиток політико-правових, конституційних механізмів оновлення та національного генезу, впровадження відповідних змін на основі чинної Конституції, орієнтуючись на максимальне використання iii внутрішнього потенціалу. Конституційна модернізація зосереджується на глибоких перетвореннях у самій практиці конституційно-правового розвитку, якісному оновленні всіх сфер сучасного конституціоналізму на основі конституційної юстиції, виборчих систем і технологій, конституційного процесуального права, міжнародного досвіду конституційного та державного будівництва.

\section{Jimepamypa:}

1. Махончук Б. С. Виборча система України як конституційно-правовий інститут. : дис. к-та юрид. наук : спец. 12.00 .02 «Конституційне право; муніципальне право». Національний юридичний університет імені Ярослава Мудрого, Міністерство освіти і науки України, Харків, 2017.

2. Баймуратов М. Парламентська виборча система: оптимальний вибір для України. Вісник Центральної виборчої комісії. 2009. № 2/3. С. 29-34.

3. Ожегов С. И. Толковый словарь русского языка: 80000 слов и фразеологических выражений. С. И. Ожегов, Н. Ю. Шведова. [4-е изд., доп.] М.: ИТИ Технологии, 2003. 944

4. Поппер К. Открытое общество и его враги. Т. 1. Чары Платона; [пер. с англ. под ред. В. Н. Садовского]. М.: Феникс, Международный фонд «Культурная инициатива», 1992. 448 с. URL: http://www.gumer.info/ bogoslov_Buks/Philos/Popp/01.php. (дата звернення: 1.11.2021). 
5. Хайек Ф. А. Дорога к рабству; [пер. с англ. М. Гнедовский]. М.:Новое изд-во, 2005. 264c. URL: http://bc.fdo.msu.ru/Nik_s/WorkFiles/DOC_files/Von_Hayek.pdf (дата звернення: 1.11.2021).

6. Афанасьєва М. В. Виборна інженерія в Україні: монографія. Одеса: «Юридична література», 2014. 384 с.

7. Афоризмы. http://www.orator.ru/churchill.html

$$
\text { Уинстон Леонард Спенсер Черчилль URL: }
$$

8. Скрытые риски открытых списков. Информационное агентство «Минпром» URL: http://minprom.ua/ page3/news14338.html. (дата звернення: 1.11.2021).

9. Правдюк А.Л.Інститут виборів як основа розвитку громадянського суспільства та розбудови демократичної держави. National law journal: teory and practice 2020. Nr. 3 (43). P. 10-17.

10. Опольська Н.М., Бабой А.М., Бабой В.С. Міжнародний захист прав людини: навчальний посібник. Вінниця: Твори. 2021. 408 с.

11. Бебик В. М. Менеджмент виборчої кампанії: ресурси, технології, маркетинг: навч.метод. посіб. К. : МАУП, 2001. 216 с

12. Здіорук С. I. Проблеми функціонування політичних партій України в системі владних відносин : монографія. К. : НІСД, 2001. 144 с.

13. Сайт made for minds URL: https://www.dw.com/uk/ a-47739550

14. Платон. Собрание сочинений: В 4 т. Т. 3. М., 1994.

15. Политическое управление. М.: Издво РАГС, 1996. 347 с.

16. Caprara, GV., Schwartz, Sh., Capanna, C., Vecchione, M., Barbaranelli, C., 2006. 'Personality and Politics: Values, Traits, and Political Choice'. Political Psychology, Vol.27, №1, p.1-28. URL: http://www.jstor.org/stable/3792381 .

17. Кот М. Учатся ли политические партии? Оценка эффективности политической игры польских партий в процессе принятия избирательного закона в 2001 году. Сощиология: теория, методы, маркетинг. 2005. № 2. С. 98-115.

18. Крусян А. Р. Науково-практична парадигма конституційних перетворень в Україні. Актуальні проблеми держави і права. 2011. Вип. $62.756 \mathrm{c.}$

19. Устименко С. Новости российского рынка избирательных технологий. Власть. 1999. № 8. C. 25-28.

20. Про засади внутрішньої та зовнішньої політики» від 8 серпня. 2018 р.: Закон України. Законодавство України. URL: https://zakon.rada.gov.ua/laws/show/2411-17\#Техt (дата звернення: 1.11.2021).

21. Михальченко М.І., Горєлов М.Є., Дергачов О.П. та ін. Політичні зміни в Україні в контексті трансформаційної і модернізаційної парадигм: порівняльний аналіз. Сучасна українська політика: Аналітичні доповіді Ін-ту політич. і етнонац. дослід. ім. І.Ф. Кураса НАН України, 2008. 7-88.

22. Політична система сучасної України: особливості становлення : навч. посіб. для студ. вищ. закл. освіти / за ред. В. М. Рудича. К. : Парлам. вид-во, 1998. 327 с.

\section{References:}

1. Makhonchuk, B. S. (2017). Vyborcha systema Ukrainy yak konstytutsiino-pravovyi instytut. [The electoral system of Ukraine as a constitutional and legal institution.] Candidate's thesis. Kharkiv: Yaroslav the Wise National University of Law. [in Ukrainian].

2. Baimuratov, M. (2009). Parlamentska vyborcha systema: optymalnyi vybir dlia Ukrainy. [ Parliamentary electoral system: the best choice for Ukraine]. Visnyk Tsentralnoi vyborchoi komisii.- Bulletin of the Central Election Commission. 2/3,29-34 [in Ukrainian].

3. Ozhegov, S. I. (2003). Tolkovyj slovar' russkogo jazyka : 80000 slov i frazeologicheskih vyrazhenij.[Explanatory dictionary of the Russian language: 80,000 words and phraseological expressions.] [in Russia ]. 
4. Popper, K. (1992). Otkrytoe obshhestvo i ego vragi. T. 1. Chary Platona [ The open society and its enemies. T. 1. Enchantment of Plato] V. N. Sadovskoho (Ed.). Moscow: Phoenix, International Foundation "Cultural Initiative" Retrieved from http://www.gumer.info/ bogoslov_Buks/Philos/Popp/01.php. [in Ukrainian].

5. Khaiek, F. A. (2005). Doroga $k$ rabstvu [Road to slavery]. (M. Hnedovskyi, Trans). Moscow.: New publishing house. Retrieved from http://bc.fdo.msu.ru/Nik_s/WorkFiles/DOC_files/ Von_Hayek.pdf [in Russia ].

6. Afanasieva, M. V. (2014). Vyborna inzheneriia v Ukraini [Elective engineering in Ukraine]. Odessa: "Legal Literature"[in Ukrainian].

7. Aforizmy. Uinston Leonard Spenser Cherchill'. Aphorisms. Winston Leonard Spencer Churchill. Retrieved from http://www.orator.ru/churchill.html [in Russia ].

8. Skrytye riski otkrytyh spiskov. Informacionnoe agentstvo «Minprom» [ Hidden risks of open lists. Information agency "Minprom"] Retrieved from http://minprom.ua/ page3/news 14338.html. [in Ukrainian].

9. Pravdiuk, A.L. (2020). Instytut vyboriv yak osnova rozvytku hromadianskoho suspilstva ta rozbudovy demokratychnoi derzhavy.[ The Institute of Elections is the basis for the development of the community society and the development of a democratic state.] Nacional'nyj juridicheskij zhurnal: teorija i praktika - National law journal: teory and practice 3 (43). P. 10-17. [in Ukrainian].

10. Opolska, N.M., Baboi., A.M., \& Baboi, V.S. (2021). Mizhnarodnyi zakhyst prav liudyny[International protection of human rights] Vinnytsia: Works. [in Ukrainian].

11. Bebyk, V. M. (2001). Menedzhment vyborchoi kampanii: resursy, tekhnolohii, marketynh [Election campaign management: resources, technologies, marketing]. Kyiv. : MAUP [in Ukrainian].

12. Zdioruk, S. I.(2001). Problemy funktsionuvannia politychnykh partii Ukrainy $v$ systemi vladnykh vidnosyn[Problems of functioning of political parties of Ukraine in the system of power relations]. Kyiv. : NISS[in Ukrainian].

13. Sait made for minds [Website made for minds] Retrieved from https://www.dw.com/uk/ a-47739550[in Ukrainian].

14. Platon, (1994), Sobranie sochinenij [Collected Works], Moscow, Russia, available at : http://read.virmk.ru/p/Platon.htm. [in Russia ].

15. Politicheskoe upravlenie[Political management]. Moscow.: Izdvo RAGS

16. Caprara, GV., Schwartz, Sh., Capanna, C., Vecchione., \& M., Barbaranelli, C.,(2006) 'Personality and Politics: Values, Traits, and Political Choice'. Political Psychology[in English]

17. Kot, M.(2005). Uchatsja li politicheskie partii? Ocenka jeffektivnosti politicheskoj igry pol'skih partij v processe prinjatija izbiratel'nogo zakona v 2001 godu [ Are political parties learning? Evaluation of the effectiveness of the political game of Polish parties in the process of adopting the electoral law in 2001.] Sociologija: teorija, metody, marketing.- Sociology: theory, methods, marketing, 2,98-115. [in Ukrainian].

18. Krusian, A. R (2011) Naukovo-praktychna paradyhma konstytutsiinykh peretvoren v Ukraini [Scientific and practical paradigm of constitutional transformations in Ukraine] Aktualni problemy derzhavy i prava - Current issues of state and law, 62, 756 [in Ukraine].

19. Ustimenko, S.(1999) Novosti rossijskogo rynka izbiratel'nyh tehnologij[News of the Russian market of electoral technologies.] Vlast-Power, 8, 25-28 [in Russia].

20. Zakon Ukrainy Pro zasady vnutrishnoi ta zovnishnoi polityky» 8 serpnia. $2018 \mathrm{r}$ [Law of Ukraine on the principles of domestic and foreign policy activity from August 8. 2018] (2018, August 8) Retrieved from zakon.rada.gov.ua/laws/show/2411-17\#Text [in Ukrainian].

21. Mykhal'chenko, M.I. Horielov, M.Ye. and Derhachov, O.P. (2008), "Political changes in Ukraine in the context of transformation and modernization paradigms: a comparative analysis", 
Suchasna ukrains'ka polityka: Analitychni dopovidi In-tu politych. i etnonats. doslid. im. IF Kurasa NAN Ukrainy, pp. 7-88.

22. Rudych, V. M. (Eds.). (1998) Politychna systema suchasnoi Ukrainy: osoblyvosti stanovlennia [The political system of modern Ukraine: features of formation] Kyiv. : Parlam. kind of. [in Ukrainian]. 